\title{
Identification, Characterization, and Distribution of Acidovorax avenae subsp. avenae Associated with Creeping Bentgrass Etiolation and Decline
}

Paul R. Giordano, Department of Plant, Soil and Microbial Sciences, Michigan State University, East Lansing 48824; Arielle M. Chaves and Nathaniel A. Mitkowski, Department of Plant Sciences and Entomology, University of Rhode Island, Kingston 02881; and Joseph M. Vargas, Jr., Department of Plant, Soil and Microbial Sciences, Michigan State University

\begin{abstract}
Giordano, P. R., Chaves, A. M., Mitkowski, N. A., and Vargas, J. M., Jr. 2012. Identification, characterization, and distribution of Acidovorax avenae subsp. avenae associated with creeping bentgrass etiolation and decline. Plant Dis. 96:1736-1742.

Bacterial etiolation and decline caused by Acidovorax avenae subsp. avenae is an emerging disease of creeping bentgrass (Agrostis stolonifera) in and around the transition zone, a unique area of turfgrass culture between cool and warm regions of the United States. It is suspected that the disease has been present for many years, although diagnosis of the first occurrence was not reported until 2010. Solicitation of samples from golf courses in 2010 and 2011 was undertaken to investigate the prevalence and dissemination of Acidovorax avenae subsp. avenae on creeping bentgrass. At least 21 isolates from 13 states associated with these outbreaks on golf courses were confirmed as $A$. avenae subsp. avenae by pathogenicity assays and $16 \mathrm{~S}$ rDNA sequence

analysis at two independent locations. Pathogenicity testing of bacterial isolates from creeping bentgrass samples exhibiting heavy bacterial streaming confirmed $A$. avenae subsp. avenae as the only bacterium to cause significant disease symptoms and turfgrass decline. Host range inoculations revealed isolates of A. avenae subsp. avenae to be pathogenic on all Agrostis stolonifera cultivars tested, with slight but significant differences in disease severity on particular cultivars. Other turfgrass hosts tested were only mildly susceptible to Acidovorax avenae subsp. avenae infection. This study initiated research on $A$. avenae subsp. avenae pathogenicity causing a previously uncharacterized disease of creeping bentgrass putting greens in the United States.
\end{abstract}

Creeping bentgrass (Agrostis stolonifera L.) is one of the most widely used turfgrass species on golf course putting greens in the United States. Most of the destructive diseases afflicting creeping bentgrass are caused by fungal pathogens, and are collectively managed by fungicide applications, host resistance, and integrated cultural practices. Bacterial diseases of turfgrasses however, are uncommon. To date, the only notable bacterial pathogens to cause significant damage to turfgrass are in the genus Xanthomonas, which have been shown to elicit disease in vegetatively propagated creeping bentgrass such as 'Toronto C-15' (24) and annual bluegrass (Poa annua L.) $(2,21,23)$.

Summer stress and extreme weather conditions, particularly in the "transition zone", make managing creeping bentgrass a challenge in several regions of the United States. This unique region of the United States, from the coastal states of Delaware, Maryland, and North Carolina and stretching eastward to Oklahoma and Kansas, creates difficult growing conditions for cool-season turfgrasses in the summer months. Recently, a bacterial pathogen within the genus Acidovorax has been detected in association with creeping bentgrass decline and etiolation in the United States (12). Symptoms of the disease on golf greens begin as small $(15$ to $30 \mathrm{~cm})$, irregular-shaped areas of foliar discoloration progressing from green to a light-green or yellow appearance. Often associated with discoloration, the affected creeping bentgrass rapidly etiolates, producing elongated, yellow blades of grass with stems that extend 0.75 to $4 \mathrm{~cm}$ above the turfgrass canopy. Although it is initially observed as a cosmetic problem, high summer temperatures $\left(>30^{\circ} \mathrm{C}\right)$ lead to thinning and necrosis of the foliar canopy, leaving

Corresponding author: P. R. Giordano, E-mail: giorda13@msu.edu

* The $\boldsymbol{e}$-Xtra logo stands for "electronic extra" and indicates that two supplementary figures are available online.

Accepted for publication 22 June 2012.

http://dx.doi.org/10.1094/PDIS-04-12-0377-RE

(C) 2012 The American Phytopathological Society irregularly shaped areas of dead grass in a creeping bentgrass sward. Initial symptoms may be confused with other diseases or conditions on creeping bentgrass, making diagnosis of the problem difficult. Damage from the disease is most severe on highly maintained, intensively managed putting greens, and symptoms first appear on peripheral or outer edge areas of putting greens, which tend to be the most stressed or trafficked due to frequent and repetitive mowing and rolling practices.

The genus Acidovorax contains many plant-pathogenic species and subspecies that cause a wide range of economically important diseases on monocotyledonous and dicotyledonous plants, including corn, watermelon, rice, anthurium, and orchids. Acidovorax avenae consists of three subspecies that differ mainly in their host range. A. avenae subsp. avenae is pathogenic on members of the family Poaceae $(3,14,15,22,27,29)$, A avenae subsp. citrulli is pathogenic on members of the family Cucurbitaceae $(15,29)$, and A. avenae subsp. cattleyae is pathogenic on species of Cattleya and Phalaenopsis only (1).

Aside from the initial isolation and identification of A. avenae subsp. avenae found in association with an emerging enigmatic syndrome plaguing golf course putting greens in the United States (12) and Japan (10), there has been limited research on Acidovorax spp. affecting amenity turfgrass. An objective of this research was to characterize bacteria isolated from symptomatic turfgrass, their pathogenicity on creeping bentgrass, and their association with the newly emerging etiolation and decline disease of creeping bentgrass on golf courses in the United States.

\section{Materials and Methods}

Research sites. The isolation, identification, and inoculation of the bacterial specimens from creeping bentgrass took place at two sites during 2009 to 2011. Researchers at Michigan State University (MSU) and the University of Rhode Island (URI) worked collaboratively, using slightly different methodologies.

Isolation. During 2009 to 2011, samples of affected turfgrass from golf course putting greens were evaluated for common turfgrass fungal pathogens as well as bacteria by observing leaves, stems, and roots for common signs and symptoms of infection. Pathogen isolation from sample plugs at MSU was conducted at 
MSU after microscopic examination revealed bacterial streaming from the cut ends of individual leaves. Stems and leaves of affected tissues were cut into 1- to 4-mm-long sections, surface disinfested with $5 \%$ sodium hypochlorite solution for $1 \mathrm{~min}$ followed by a rinse in sterile distilled water for $1 \mathrm{~min}$, and either plated onto nutrient agar (NA) (BD Difco) or put into Eppendorf tubes with 20 $\mu \mathrm{l}$ of sterile phosphate-buffered saline (PBS) solution ( $\mathrm{pH} 7.0)$ and macerated with a sterile scalpel. In the latter case, serial dilutions up to $1 \times 10^{-4}$ were performed in sterile PBS, with $10 \mu \mathrm{l}$ of each suspension plated onto NA medium and incubated at room temperature for 3 to 5 days. At URI, symptomatic leaf blades were put onto a glass slide in $200 \mu \mathrm{l}$ of sterile water and, when bacterial streaming was observed, $1 \mu$ l of exudate was removed and plated onto yeast extract-dextrose-calcium carbonate agar medium (YDC) (25). Single colonies that developed were then streaked onto new NA (MSU) or YDC (URI) plates to obtain pure cultures for subsequent identification and inoculation experiments. All isolates were maintained on solid nutrient medium (King's B, NA, or YDC) for short-term use, or grown in $25 \mathrm{ml}$ of trypticase soy broth (TSB) medium for 3 to 5 days, after which $1 \mathrm{ml}$ of suspension was transferred to CryoTubes (Thermo-Fisher Scientific Inc.) and stored at $-80^{\circ} \mathrm{C}$ in $30 \%$ glycerol for long-term storage.

Electron microscopy. Naturally infected symptomatic leaves and stems of creeping bentgrass were cut into 2-mm-long sections for observation via electron microscopy. Samples were fixed at $4^{\circ} \mathrm{C}$ for $2 \mathrm{~h}$ in $4 \%$ glutaraldehyde buffered with $0.1 \mathrm{M}$ sodium phosphate at $\mathrm{pH} 7.4$. Following a brief rinse $(0.5 \mathrm{~h})$ in the buffer, samples were dehydrated in an ethanol series $(25,50,75$, and $95 \%)$ for $30 \mathrm{~min}$ at each graduation with three 10-min changes in $100 \%$ ethanol. Samples were critical point dried in a critical point dryer (Model 010, Balzers Union Ltd.) using liquid carbon dioxide as the transitional fluid. Samples were mounted on aluminum stubs using high-vacuum carbon tabs (SPI Supplies), then coated with osmium (approximately $10 \mathrm{~nm}$ in thickness) in an NEOC-AT osmium coater (Meiwafosis Co., Ltd.). Samples were examined in a JEOL JSM-7500F (cold-field emission electron emitter) scanning electron microscope (JEOL Ltd.). Digital images were acquired using Analysis Pro software (version 3.2; Olympus Soft Imaging Solution Corp.).

Fatty acid analysis. The organism isolated at MSU (MSU1) was initially identified by fatty acid methyl ester analysis (FAME). The isolate was submitted for cellular fatty acid analysis for species identification. Microcheck, a commercial service, was used to perform the analysis and isolates were submitted per the preparation instructions of the company according to their published procedures.

Enzyme-linked immunosorbent assay identification. The URI bacterial isolates were identified in September 2010 with an indirect enzyme-linked immunosorbent assay (ELISA) kit from Agdia (catalog number BRA 41900), using an alkaline phophatase label following the manufacturer's published protocol. Bacteria colonies $(24 \mathrm{~h}$ old $)$ were transferred from YDC plates with a sterile toothpick into individual well plates for testing. A positive reading was indicated by a color change from clear to yellow. The positive control (A. avenae) included with the kit tested positive and the negative control was negative.

16S rDNA sequencing and identification at MSU. Isolates of the most commonly recovered bacteria were grown for 3 to 5 days on King's B medium at room temperature. Single colonies were picked with sterile toothpicks and transferred into $100 \mu$ of DNA lysis buffer (0.05 M KCl, 0.01 M Tris, and 1\% Tween 20). Suspensions were incubated at $100^{\circ} \mathrm{C}$ for $10 \mathrm{~min}$, and supernatant was used directly as a template for polymerase chain reactions (PCRs). PCRs contained 50 to $100 \mathrm{ng}$ of total DNA template. All PCR amplifications were performed in a $25-\mu l$ reaction mixture containing $1 \mu \mathrm{l}$ of DNA template solution, and PCR reactants supplied by Invitrogen Co., including $18.1 \mu \mathrm{l}$ of sterile distilled water, $2.5 \mu \mathrm{l}$ of $10 \times$ PCR buffer, $0.2 \mu \mathrm{l}$ of $10 \mathrm{mM}$ dNTP mixture, $1 \mu \mathrm{l}$ of $50 \mathrm{mM}$ $\mathrm{MgCl}_{2}$ solution, $1 \mu \mathrm{l}$ of each primer 63f (5'-CAGGCCTAACA CATGCAAGTC)/1387r (5'-GGGCGGWGTGTACAAGGC) (20) at a concentration of $10 \mu \mathrm{M}$, and $0.2 \mu \mathrm{l}$ of Taq DNA polymerase at $5 \mathrm{U} / \mu \mathrm{l}$. All reaction tubes were placed in an Applied Biosystems GeneAmp 2700 thermocycler96 programmed as follows: $5 \mathrm{~min}$ at $95^{\circ} \mathrm{C}$; followed by 35 cycles of $1 \mathrm{~min}$ at $95^{\circ} \mathrm{C}, 1 \mathrm{~min}$ at $55^{\circ} \mathrm{C}$, and $1.5 \mathrm{~min}$ at $72^{\circ} \mathrm{C}$; with a final extension of $5 \mathrm{~min}$ at $72^{\circ} \mathrm{C}$. All PCR products were run on a $1 \%$ gel and stained with ethidium bromide to confirm amplification of the $16 \mathrm{~S}$ region. PCR products were purified with the QIA-quick PCR Purification Kit (Qiagen) according to the manufacturer's protocol. Purified DNA was recovered, standardized to $10 \mathrm{ng} / \mu \mathrm{l}$ via a NanoDrop ND-1000 spectrophotometer (NanoDrop Technologies), and sequenced at the MSU Research Technology Support Facility using an ABI 3730 automated sequencer.

16S rDNA sequencing and identification at URI. Ribosomal DNA (16S) was amplified on a PTC-100 thermocycler using the primers $\mathrm{pA}(=8 \mathrm{~F})\left(5^{\prime}\right.$-AGAGTTTGATCMTGGCTCAG-3')/pHr $\left(5^{\prime}-\right.$ AAGGAGGTGATCCANCCRCA-3') (32). Briefly, single colonies of bacteria were placed into $100 \mu$ of sterile water and frozen and thawed twice in order to obtain template DNA. All PCR amplifications were performed in a $25-\mu \mathrm{l}$ reaction mixture containing $1 \mu \mathrm{l}$ of template DNA with PCR reactants supplied by Promega Corp., including $14 \mu \mathrm{l}$ of sterile distilled water, $2.5 \mu \mathrm{l}$ of $25 \mathrm{mM} \mathrm{MgCl}{ }_{2}$, $2.5 \mu \mathrm{l}$ of $10 \times$ magnesium free buffer, $1.3 \mu \mathrm{l}$ of $200 \mu \mathrm{M}$ dNTPs, and $0.5 \mu \mathrm{l}$ of each $10 \mu \mathrm{M}$ primer. All reaction tubes were placed into the thermal cycler at $94^{\circ} \mathrm{C}$ and 0.5 units of Taq DNA polymerase (Promega Corp.) were then added to each tube. The thermocycler program was $1 \mathrm{~min}$ at $94^{\circ} \mathrm{C}, 1 \mathrm{~min}$ at $51^{\circ} \mathrm{C}$, and $2 \mathrm{~min}$ at $72^{\circ} \mathrm{C}$ repeated 25 times; followed by $5 \mathrm{~min}$ of extension at $72^{\circ} \mathrm{C}$. PCR products were purified using a QIAquick PCR Purification Kit (Qiagen). The DNA samples were sequenced at the URI Genomics and Sequencing Center using an Applied Biosystems 3130xl Genetic Analyzer.

Inoculation experiments (MSU). A. avenae subsp. avenae (MSU1), Stenotrophomonas maltophilia (MSU7), Herbaspirillum seropedicae (MSU11), and Ralstonia pickettii (MSU12), initially isolated from serial dilutions of symptomatic samples, were used in inoculation experiments with seed-grown Agrostis stolonifera 'Penn-A4'. Seed were sown in Styrofoam cups $(8.5$ by $10 \mathrm{~cm})$ filled with $80: 20 \mathrm{sand} /$ peat at a rate of $0.0049 \mathrm{~kg} / \mathrm{m}^{2}$. Plants were allowed to grow for 8 to 10 weeks until pots were sufficiently filled with mature turfgrass. Fertilizer (20-20-20) was applied every 2 to 3 weeks as foliar sprays, with nitrogen at a rate of $24.4 \mathrm{~kg} / \mathrm{ha}^{-1}$. Plants were trimmed at regular intervals to a height of approximately 2 to $3 \mathrm{~cm}$. Three replicate cups were included in all inoculations, and experiments were repeated once unless otherwise noted. Inoculum preparation consisted of growing pure cultures of each bacterium from frozen seed stock in $25 \mathrm{ml}$ of TSB medium for 3 to 4 days in 100-ml Erlenmeyer flasks on a rotary shaker set to $100 \mathrm{rpm}$ at room temperature $\left(20\right.$ to $\left.22^{\circ} \mathrm{C}\right)$. Before plant inoculations, cells were spun down in centrifuge tubes in a Sorvall Legend RT centrifuge at $3,761 \times g$ for $3 \mathrm{~min}$. Supernatant was decanted and cells were resuspended in $25 \mathrm{ml}$ of sterile PBS. The bacterial cell suspension was vortexed, and turbidity measured at $640 \mathrm{~nm}$. Concentrations were adjusted to range from $10^{8}$ to $10^{9}$ cells $\mathrm{ml}^{-1}$. Prior to inoculation, turfgrass foliage was trimmed with sterile scissors to approximately $3 \mathrm{~cm}$ in length and misted with sterile distilled water. Inoculation was performed by dipping sterile scissors into a bacterial suspension, trimming plants to a length of approximately 1 to $2 \mathrm{~cm}$ using the inoculated scissors, then submerging leaf tips in the same bacterial cell suspension for approximately $10 \mathrm{~s}$ by inverting the cup over liquid inoculums prep. Control plants were treated similarly, except that scissors were sterile and leaf tips were dipped in sterile PBS. Cups were transferred to a Conviron HL-E8VH growth chamber set to 12 -h day length and temperatures of 30 to $32^{\circ} \mathrm{C}$ (light) and 25 to $27^{\circ} \mathrm{C}$ (dark) at $>70 \%$ relative humidity in order to simulate environmental conditions of origin. In inoculation experiment 1, plants were kept in the growth chamber for 15 days, watered daily or as needed with deionized tap water, and trimmed every 2 to 3 days with sterile scissors to simulate turfgrass mowing events. Plants were rated every 2 to 3 days 
for disease progression and symptomology. Foliar disease symptoms were rated on a 0 -to- $100 \%$ scale, where $0=$ unaffected and $100=$ every plant is completely necrotic or dead. Pooled experimental data from repeated experiments were analyzed by analysis of variance (ANOVA) using Proc GLM in SAS (v. 9.2; SAS Institute). When a significant $F$ value was determined, means were separated by Tukey's multiple comparison test.

A second inoculation experiment at MSU used a single isolate (Acidovorax avenae subsp. avenae [MSU4]) to inoculate eight cultivars of Agrostis stolonifera (Table 1). All inoculations took place following the above-mentioned methods, all cups were replicated four times, and experiments were conducted twice. Confirmation of bacterial streaming from plants was conducted 13 to 15 days post inoculation by excising four symptomatic plants per container from the base of the shoot, cutting them into 2-to-3-mmlong sections, and observing them at $\times 200$ under a compound microscope. Positive identification of streaming was tallied for each replicate and numbers compiled to form a percentage of plants with streaming identified. Isolation of inoculated bacterium was achieved via surface disinfestation of cut tissues and subsequent plating onto King's B medium. Disease ratings were taken every 2 to 3 days for 15 days. Data from repeated experiments
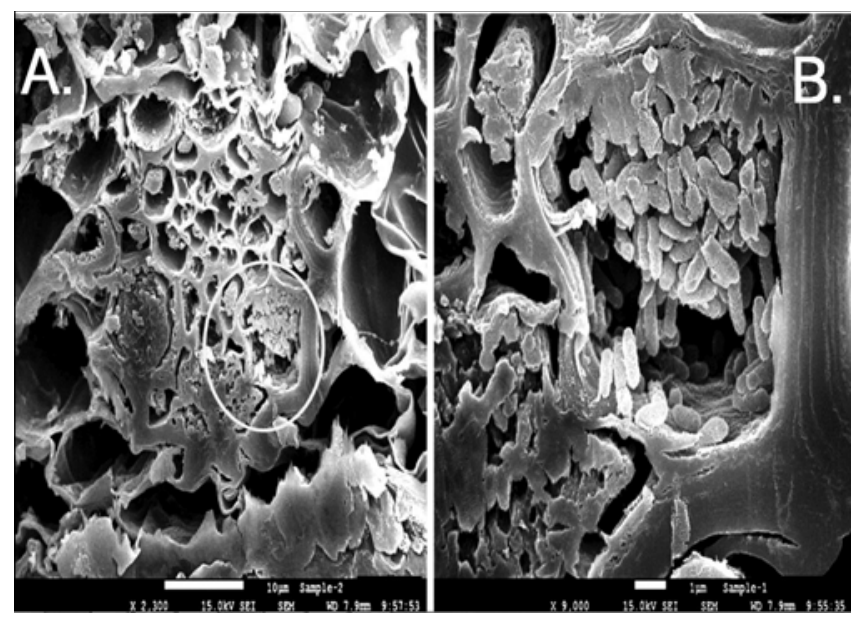

Fig. 1. Electron microscopy image of a cross section of naturally infected creeping bentgrass (Agrostis stolonifera L.) plant from a golf course putting green. A, Magnification $\times 2,300$ view of vascular bundle. Note the numerous rigid xylem vessels that are impeded. B, Magnification $\times 9,000$ view of an impeded vascular tissue showing heavy colonization by rod-shaped bacteria.

Table 1. Host range inoculations conducted at Michigan State University (MSU) and the University of Rhode Island (URI) with Acidovorax avenae subsp. avenae isolated from Agrostis stolonifera ${ }^{\mathrm{u}}$

\begin{tabular}{|c|c|c|c|}
\hline Host tested & Disease $(\%)^{\mathrm{v}}$ & Streaming from plants $(\%)^{\mathrm{w}}$ & Reisolation of A. avenea subsp. avena $e^{\mathrm{x}}$ \\
\hline \multicolumn{4}{|l|}{ MSU inoculation $(\mathrm{MSU} 4)^{\mathrm{y}}$} \\
\hline Agrostis stolonifera '007' & $47.5 \mathrm{~b}$ & $68.7 \mathrm{~b}$ & + \\
\hline A. stolonifera 'Bengal' & $50.0 \mathrm{ab}$ & $64.7 \mathrm{~b}$ & + \\
\hline A. stolonifera 'Declaration' & $32.1 \mathrm{c}$ & $48.5 \mathrm{c}$ & + \\
\hline A. stolonifera 'Tyee' & $28.1 \mathrm{c}$ & $44.5 \mathrm{c}$ & + \\
\hline A. stolonifera 'L-93' & $56.5 \mathrm{ab}$ & $64.7 \mathrm{~b}$ & + \\
\hline A. stolonifera 'Penncross' & $55.0 \mathrm{ab}$ & $68.7 \mathrm{~b}$ & + \\
\hline A. stolonifera 'Penn G-2' & $59.1 \mathrm{ab}$ & $60.7 \mathrm{~b}$ & + \\
\hline A. stolonifera 'Penn A-4' & $66.8 \mathrm{a}$ & $80.8 \mathrm{a}$ & + \\
\hline \multicolumn{4}{|l|}{ URI inoculations (URI6) ${ }^{\mathrm{z}}$} \\
\hline A. stolonifera 'Southshore' & ++ & 91.7 & + \\
\hline A. stolonifera 'Crenshaw' & ++ & 100.0 & + \\
\hline A. stolonifera 'Providence' & ++ & 100.0 & + \\
\hline A. stolonifera 'Macenzie' & ++ & 100.0 & + \\
\hline A. stolonifera 'Cato' & ++ & 100.0 & + \\
\hline A. stolonifera 'SR-1150’ & ++ & 100.0 & + \\
\hline A. stolonifera 'PennLinks' & ++ & 100.0 & + \\
\hline A. stolonifera 'PennEagle' & ++ & 91.7 & + \\
\hline A. canina 'SR7200' & ++ & 100.0 & + \\
\hline A. tenuis 'Exeter' & ++ & 100.0 & + \\
\hline A. tenuis 'Alistar' & ++ & 100.0 & + \\
\hline Lolium multiflorum 'Unknown' & + & 100.0 & + \\
\hline Роа аппиа var. аппиа & $+1-$ & 100.0 & + \\
\hline P. pratensis 'Nuglade' & $+1-$ & 100.0 & + \\
\hline Festuca rubra var. rubra 'Cindy Lou' & - & 50.0 & + \\
\hline L. perenne 'Turf Star' & - & 100.0 & + \\
\hline F. arundinacea 'Pixie' & + & 100.0 & + \\
\hline Zea mays 'Sweet Perfection' & $+/-$ & 41.7 & + \\
\hline Z. mays 'Early Choice' & $+1-$ & 100.0 & + \\
\hline Z. mays 'Jubilee' & $+1-$ & 16.7 & - \\
\hline Z. mays 'Bi-licious Hybrid' & $+/-$ & 100.0 & + \\
\hline Hordeum vulgare 'Conlon' & ++ & 50.0 & + \\
\hline Avena sativa 'Marion' & ++ & 100.0 & + \\
\hline A. sativa 'Montezuma' & ++ & 100.0 & + \\
\hline A. sativa 'Richland' & ++ & 100.0 & + \\
\hline Triticum aestivum 'Anza' & ++ & 100.0 & + \\
\hline Oryza sativa 'Nortai' & $+/-$ & 66.7 & + \\
\hline O. sativa 'Koshikari' & $+/-$ & 58.3 & + \\
\hline
\end{tabular}

" Means followed by the same letter are not significantly different according to Tukey's multiple comparison test $(P \leq 0.05)$.

${ }^{v}$ Percent disease was the mean percentage of total turf necrosis in each container. Data were pooled from initial and repeated trials of the experiment.

${ }^{w}$ Bacterial streaming (MSU) was the percentage of plants with confirmed bacterial streaming from four randomly selected shoots examined from each container (pooled $n=32$ ).

${ }^{x}$ Confirmation (+ or - ) of A. avenae subsp. avenae isolation was achieved by dilution plating and subsequent 16S rDNA sequencing.

y Disease ratings (MSU) were recorded 15 days post inoculation with Acidovorax avenae subsp. avenae (isolate MSU4).

${ }^{2}$ Disease ratings recorded 7 days post inoculation with A. avenae subsp. avenae (isolate URI6). Disease ratings (pooled $n=6$ ) were as follows: limited infection approximately $1 \mathrm{~mm}$ wide at the end of the cut blade $=-$; limited yellowing present with weak bacterial streaming $=+/-$; yellowing present in leaves, early necrosis $=+$; and severe necrosis and yellowing with heavy bacterial streaming $=++$. Bacterial streaming (URI) is from two chosen symptomatic leaves per plant (pooled $n=12$ ). Data were pooled from initial and repeated trial of the experiment. 
were pooled and analyzed by ANOVA using Proc GLM in SAS (v. 9.2; SAS Institute). When a significant $F$ value was determined, means were separated by Tukey's multiple comparison test.

Inoculation experiments at URI. Approximately 20 seeds of each type of turfgrass listed in Table 1 were sown in 4-in. (10.2 $\mathrm{cm}$ ) plastic pots in MetroMix 510 (Sun Gro Horticulture) a peat-, vermiculite-, and pine-bark-based potting mix. Seedlings were grown under greenhouse conditions and turfgrass was not trimmed prior to inoculation. Plants used were 6 to 8 weeks old, each experiment consisted of three replications of plants, and experiments were conducted twice. All inoculations included a negative control in every replicate of every experiment using sterile water. Glycerol stocks of bacteria were removed from the $-80^{\circ} \mathrm{C}$ freezer and streaked onto YDC. Cultures were grown in $40 \mathrm{ml}$ of a modified YSG broth medium (8) substituting $10 \mathrm{~g}$ of dextrose for glycerol and placed on a rotary shaker at $270 \mathrm{rpm}$ in a $28^{\circ} \mathrm{C}$ incubator. All plants were inoculated by dipping scissors into the bacterial suspension and clipping the leaves. Scissors were

Table 2. Identification of bacterial isolates cultured from symptomatic turfgrass plants collected from various geographic regions in the United States ${ }^{\mathrm{W}}$

\begin{tabular}{|c|c|c|c|c|c|}
\hline Isolate name & Host & Geographic location & BLAST results (accession number) ${ }^{x}$ & ID $(\%)^{\mathrm{y}}$ & ELISA $^{z}$ \\
\hline MSU1 & Agrostis stolonifera 'Penn G2' & Charlotte, NC & $\begin{array}{l}\text { Acidovorax avenae subsp. avenae strain ICMP } \\
3183 \text { (NR_043752) }\end{array}$ & 99.24 & NT \\
\hline MSU2 & Agrostis stolonifera 'Penn A4' & Irvine, $\mathrm{TX}$ & $\begin{array}{l}\text { Acidovorax avenae subsp. avenae strain ICMP } \\
3183 \text { (NR_043752) }\end{array}$ & 99.76 & NT \\
\hline MSU3 & Agrostis stolonifera 'Unknown' & Detroit, MI & $\begin{array}{l}\text { Ochrobactrum pseudogrignonense strain: } \\
\text { CCUG } 30717 \text { (NR_042589) }\end{array}$ & 99.50 & NT \\
\hline MSU4 & Agrostis stolonifera 'Penn A4' & Fort Worth, TX & $\begin{array}{l}\text { Acidovorax avenae subsp. avenae strain ICMP } \\
3183 \text { (NR_043752) }\end{array}$ & 99.92 & NT \\
\hline MSU5 & Agrostis stolonifera 'Penn A1' & Athens, GA & $\begin{array}{l}\text { Acidovorax avenae subsp. avenae strain ICMP } \\
3183 \text { (NR_043752) }\end{array}$ & 99.59 & NT \\
\hline MSU6 & Agrostis stolonifera 'Penn-A1/A4' & Athens, GA & $\begin{array}{l}\text { Microbacterium binotii strain CIP } \\
\text { 101303(NR_044290) }\end{array}$ & 100.0 & NT \\
\hline MSU7 & Agrostis stolonifera 'Unknown' & Silvis, IL & $\begin{array}{l}\text { Stenotrophomonas maltophilia strain } \\
\text { IAM } 12423 \text { (NR_041577) }\end{array}$ & 99.44 & NT \\
\hline MSU8 & Agrostis stolonifera 'Unknown' & Newburgh, IN & $\begin{array}{l}\text { Acidovorax avenae subsp. avenae strain ICMP } \\
3183 \text { (NR_043752) }\end{array}$ & 99.92 & NT \\
\hline MSU9 & Agrostis stolonifera 'Penn G2' & Toledo, $\mathrm{OH}$ & $\begin{array}{l}\text { Acidovorax avenae subsp. avenae strain ICMP } \\
3183 \text { (NR_043752) }\end{array}$ & 98.05 & NT \\
\hline MSU10 & Agrostis stolonifera 'Unknown' & Indianapolis, IN & $\begin{array}{l}\text { Stenotrophomonas maltophilia strain } \\
\text { IAM } 12423 \text { (NR_041577) }\end{array}$ & 99.51 & NT \\
\hline MSU11 & Agrostis stolonifera 'Unknown' & South Hamilton, MA & $\begin{array}{l}\text { Herbaspirillum seropedicae strain Z67 } \\
\text { (NR_029329) }\end{array}$ & 99.67 & NT \\
\hline MSU12 & Agrostis stolonifera 'Unknown' & St. Louis, MO & $\begin{array}{l}\text { Ralstonia pickettii strain ATCC } 27511 \\
\text { (NR_043152) }\end{array}$ & 99.42 & NT \\
\hline MSU13 & Agrostis stolonifera 'Penn G2' & Charlotte, $\mathrm{NC}$ & $\begin{array}{l}\text { Acidovorax avenae subsp. avenae strain ICMP } \\
3183 \text { (NR_043752) }\end{array}$ & 95.37 & NT \\
\hline MSU14 & Agrostis stolonifera 'Penn G2' & Charlotte, NC & $\begin{array}{l}\text { Acidovorax avenae subsp. avenae strain ICMP } \\
3183 \text { (NR_043752) }\end{array}$ & 100.0 & NT \\
\hline URI1 & Agrostis stolonifera 'Unknown' & Greenwich, CT & $\begin{array}{l}\text { Acidovorax avenae subsp. avenae } \\
\text { ATCC } 19860 \text { (CP002521) }\end{array}$ & 98.86 & + \\
\hline URI2 & Agrostis stolonifera 'Unknown' & Walpole, MA & $\begin{array}{l}\text { Acidovorax avenae subsp. avenae } \\
\text { ATCC } 19860 \text { (CP002521) }\end{array}$ & 100.0 & + \\
\hline URI3 & Agrostis stolonifera 'Unknown' & Midlothian, IL & $\begin{array}{l}\text { Acidovorax avenae subsp. avenae } \\
\text { ATCC } 19860 \text { (CP002521) }\end{array}$ & 100.0 & + \\
\hline URI4 & Agrostis stolonifera 'Unknown' & Deal, NJ & $\begin{array}{l}\text { Acidovorax avenae subsp. avenae } \\
\text { ATCC } 19860 \text { (CP002521) }\end{array}$ & 100.0 & + \\
\hline URI5 & Agrostis stolonifera 'Unknown' & Amagansett, NY & $\begin{array}{l}\text { Acidovorax avenae subsp. avenae } \\
\text { ATCC } 19860 \text { (CP002521) }\end{array}$ & 100.0 & + \\
\hline URI6 & Agrostis stolonifera 'L-93' & Richmond, VA & $\begin{array}{l}\text { Acidovorax avenae subsp. avenae } \\
\text { ATCC } 19860 \text { (CP002521) }\end{array}$ & 99.77 & + \\
\hline URI7 & Agrostis stolonifera 'Unknown' & Willoughby, $\mathrm{OH}$ & $\begin{array}{l}\text { Acidovorax avenae subsp. avenae } \\
\text { ATCC } 19860 \text { (CP002521) }\end{array}$ & 99.93 & + \\
\hline URI8 & Agrostis stolonifera 'Alpha' & Bethlehem, PA & $\begin{array}{l}\text { Acidovorax avenae subsp. avenae } \\
\text { ATCC } 19860 \text { (CP002521) }\end{array}$ & 99.93 & + \\
\hline URI9 & Agrostis stolonifera 'Unknown' & Lakeville, MA & $\begin{array}{l}\text { Acidovorax avenae subsp. avenae } \\
\text { ATCC } 19860 \text { (CP002521) }\end{array}$ & 99.93 & + \\
\hline URI10 & Agrostis stolonifera 'Unknown' & Charlotte, NC & $\begin{array}{l}\text { Acidovorax avenae subsp. avenae } \\
\text { ATCC } 19860 \text { (CP002521) }\end{array}$ & 100.0 & + \\
\hline URI11 & Agrostis stolonifera 'Unknown' & Dayton, $\mathrm{OH}$ & $\begin{array}{l}\text { Acidovorax avenae subsp. avenae } \\
\text { ATCC } 19860 \text { (CP002521) }\end{array}$ & 99.86 & + \\
\hline URI12 & Agrostis canina L. 'Unknown' & Haverhill, MA & $\begin{array}{l}\text { Acidovorax avenae subsp. avenae } \\
\text { ATCC } 19860 \text { (CP002521) }\end{array}$ & 100.0 & + \\
\hline URI13 & Agrostis canina L. 'Greenwich' & Charlestown, RI & $\begin{array}{l}\text { Acidovorax avenae subsp. avenae } \\
\text { ATCC } 19860 \text { (CP002521) }\end{array}$ & 100.0 & + \\
\hline
\end{tabular}

${ }^{\mathrm{w}}$ Information was derived from research at Michigan State University (MSU) and the University of Rhode Island (URI) using two different sets of universal bacterial $16 \mathrm{~S}$ primers.

${ }^{x}$ BLAST results indicate the top hits from each organism represented in the BLAST National Center for Biotechnology Information database. ICMP: International Collection of Microorganisms from Plants, CCUG: Culture Collection, University of Göteborg, Sweden, CIP: Collection de l'Institut Pasteur, ATCC: American Type Culture Collection.

${ }^{y}$ ID $(\%)$ represents the percentage of nucleotide matches from the queried organism $16 \mathrm{~S}$ rDNA to the indicated organism identified as the top hit from the BLAST database.

${ }^{\mathrm{z}}$ Enzyme-linked immunosorbent assay (ELISA) identification of URI isolates was carried out using an indirect ELISA kit from Agdia (catalog number BRA 41900) specific to Acidovorax avenae; NT = not tested, and + indicates a positive presence. 
sterilized between isolate inoculations by spraying with $70 \%$ ethanol. Turf grasses were clipped to 2 to $4 \mathrm{~cm}$ in height during inoculation. For the larger non-turfgrass species, three plants were sown into each replicate pot, including corn, barley, oat, wheat, and rice. For these larger plants, 2 to $4 \mathrm{~cm}$ of tissue was cut from the leaf tip during inoculation. The URI growth chamber temperatures were 29 to $31^{\circ} \mathrm{C}$ during the daylight phase and 25 to $24^{\circ} \mathrm{C}$ during the night phase. Plants were misted once per day with a plastic spray bottle to increase the relative humidity inside the chamber. The plants were under continuous illumination and were not clipped after inoculation. Initial symptoms were visible 3 days after inoculation, and plants were rated for disease symptoms 7 days after inoculation. When symptoms were visible on clipped leaf blades, visual ratings of disease on plants were taken as severe, moderate, or ambiguous/mild, $(++,+,+-$, , or - , respectively). Disease ratings were followed by microscopic observations of two symptomatic leaf blades per plant for bacterial streaming. When bacterial streaming was present, bacteria were reisolated using the methods described above.

\section{Results}

Isolation. Dilution plating and isolation from infected turfgrass leaves and stems consistently resulted in gram-negative, rodshaped, nonfluorescent bacterial colonies on King's B medium. The colonies on YDC medium were white to cream with tan to
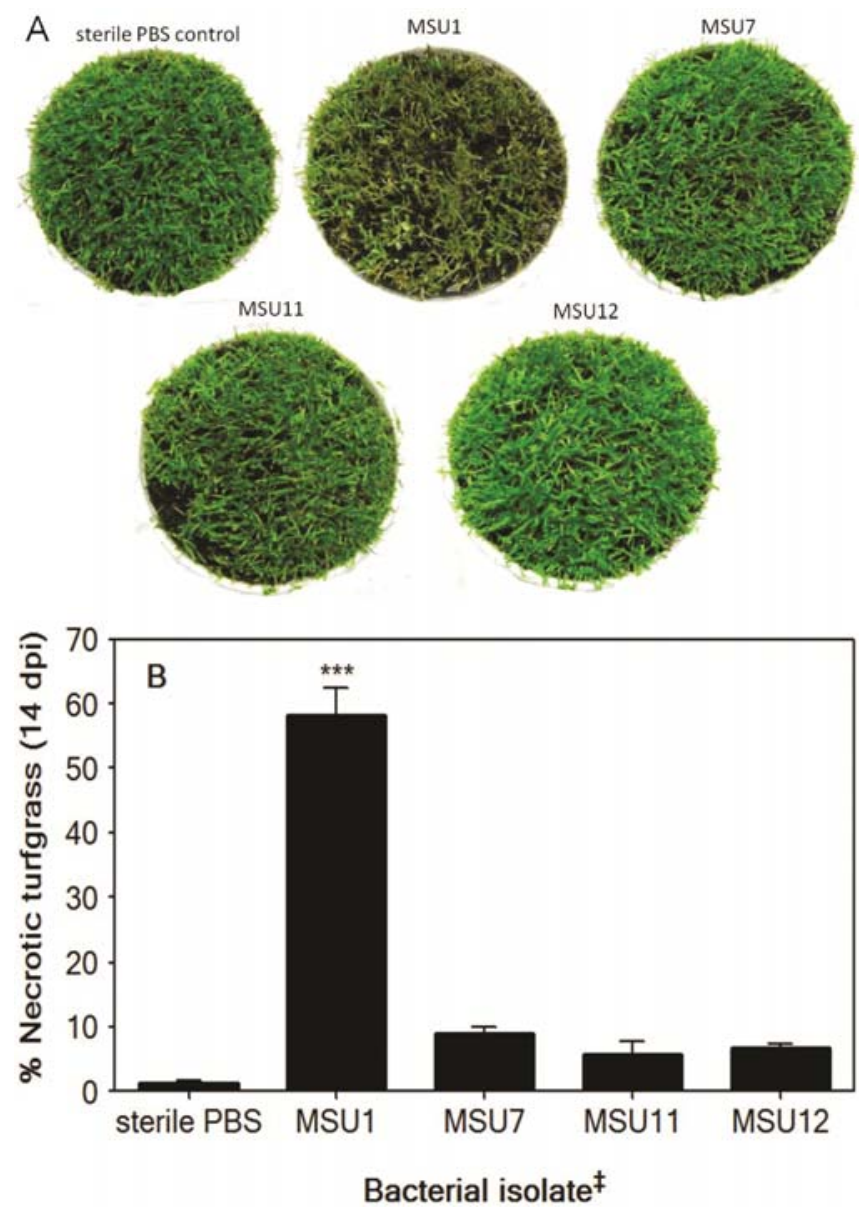

Fig. 2. Percent (\%) necrosis of creeping bentgrass (Agrostis stolonifera 'Penn-A4') after inoculations with isolates of bacteria from infected golf course samples. A, Creeping bentgrass cups after inoculation with different bacterial isolates and 15 days of incubation. B, Percent necrosis ratings after inoculation and 15 days of incubation. ₹ Isolates were identified via 16S rDNA sequencing: MSU11 (Herbaspirillum seropedicae; [NR_029329]); MSU1 (Acidovorax avenae subsp. avenae; [NR_043752]), MSU12 (Ralstonia pickettii; [NR_043152]), and MSU7 (Stenotrophomonas maltophilia; [NR_041577]). PBS is sterile phosphate-buffered saline control. Bars represent \pm standard error of mean; ${ }^{* \star *}$ mean is significantly different than all others according to Tukey's multiple comparison test $(P<0.0001)$. brown centers, convex, smooth, and 2 to $3 \mathrm{~mm}$ in diameter after 3 days of growth.

Electron microscopy. In the samples observed under scanning electron microscopy, the vascular cells had abundant rod-shaped bacterial colonization in the adaxial surface region. The vascular bundle showed abnormal impediment by bacteria (Fig. 1) that were not present in tissues from asymptomatic plants. The scanning electron microscopy images revealed the presence of bacteria in all of the symptomatic plants studied. A large number of bacteria were observed in numerous adaxial and abaxial vascular spaces. Fungi were not detected in any of the electron microscopic analyses.

Fatty acid analysis. The FAME identification system determined that the organism initially isolated from creeping bentgrass (MSU1) had similarity indices closest to Acidovorax avenae subsp. cattleyae (0.890) and A. avenae subsp. avenae (0.853) (data not shown).

16S rDNA sequencing and ELISA identification. From 2009 to 2011,28 isolates of suspected causal bacterial agents were cultured from infected creeping bentgrass collected from more than 25 golf courses in 15 states by both MSU and URI researchers (Table 2). BLAST (NCBI BLAST Web Server) comparisons of the ribosomal DNA sequences from these isolates indicated high similarity indices (>95\%) to A. avenae subsp. avenae in a majority of the isolated organisms. The most common genus that colonized the stem and leaf tissues of infected plants was Acidovorax. Other isolated bacterial genera were cultured and stored for further classification and pathogenicity testing.

Inoculation experiments at MSU. In the first experiment, percent necrosis of creeping bentgrass was significantly greater after 15 days of incubation in MSU1-inoculated plants compared with all other bacterial inoculants and the sterile water control (Fig. 2). None of the other bacteria isolated from creeping bentgrass $(S$. maltophilia, $R$. pickettii, and $H$. seropedicae) produced significant turfgrass damage or necrosis when compared with the sterile water control (Fig. 2), and post-inoculation bacterial streaming from lower tissues was observed only in plants inoculated with MSU1 (data not shown).

In the second inoculation experiment at MSU, the eight cultivars of A. stolonifera tested exhibited varying levels of susceptibility; however, all were susceptible to infection by A. avenae subsp. avenae isolate MSU4 (Table 1$)$. Significantly less $(P \leq 0.05)$ disease was detected on 'Tyee' and 'Declaration' compared with the other cultivars tested after 15 days of incubation (Table 1). The cultivar ' 007 ' had significantly less disease $(P=0.003)$ than 'PennA4' but not 'Bengal', 'L-93', 'Penncross', or 'Penn G-2'. (Table $1)$. Declaration and Tyee showed a significant $(P \leq 0.05)$ reduction in the percentage of plants with bacterial streaming compared with all other cultivars, while 'Penn-A4' had higher observed percentages of bacterial streaming from plant tissues than all other cultivars $(P \leq 0.05)$ (Table 1$)$.

Inoculation experiments at URI. Inoculation with $A$. avenae subsp. avenae (RI6) at URI confirmed the pathogenicity of the bacterium on creeping bentgrass. All cultivars of Agrostis stolonifera tested displayed high levels of susceptibility, with significant chlorosis and necrosis of inoculated plants (Table 1). Other $A g$ rostis spp. (A. canina and A. tenuis) were also highly susceptible to Acidovorax avenae subsp. avenae infection (Table 1). Other turfgrass genera which were mildly susceptible to infection by the URI6 isolate include Lolium multiflorum and Festuca arundinacea; however, infection was limited to isolated areas of individual leaves, and progression of necrosis was not complete (Table 1). Disease severity was low on the tested cultivars of $P$. annua, $P$. pratensis, F. rubra, L. perenne, Zea mays, and Oryza sativa, with little to no necrosis progressing past the point of inoculation. Pathogenicity on the tested cultivars of Hordeum vulgare, Avena sativa, and Triticum aestivum was significant, with extensive chlorosis, heavy bacterial streaming, and eventual necrosis of inoculated tissues. Bacterial streaming could be observed on all hosts tested, even those that lacked disease symptoms; however, 
in asymptomatic hosts, weak bacterial streaming was detected only from tissues inoculated directly with a bacterial suspension (Table 1).

\section{Discussion}

The infection of creeping bentgrass by Acidovorax avenae subsp. avenae in golf course putting green settings has not been characterized in the United States until this point. Symptoms of etiolation, necrosis, and thinning of the turfgrass stand in irregular areas become noticeable in many locations under high temperatures accompanied by severe physical or mechanical stress. Consistent isolation of high populations of A. avenae subsp. avenae from diseased creeping bentgrass from several locations in the United States and results of subsequent inoculation studies have shown that the bacterium is capable of causing symptoms of discoloration, thinning, and necrosis on creeping bentgrass. In addition, the bacterium caused minor disease symptoms on other turfgrass hosts such as Agrostis tenuis, $P$. annua, and F. arundinacea in controlled environment studies.

Symptoms on host plants (e.g., Avena sativa, Z. mays, S. officianarum, and $O$. sativa) infected by Acidovorax avenae subsp. avenae typically consist of leaf streaking, brown stripes, and occasional rots; however, in rice, $A$. avenae subsp. avenae infection can cause curving of the leaf sheath and an abnormal elongation of the mesocotyl (16). The similar symptomology associated with infected creeping bentgrass etiolation must be further explored. Creeping bentgrass etiolation and subsequent decline has been hypothesized to be caused by numerous biotic and abiotic effects $(9,18)$; however, a pathogenic agent has never been thoroughly characterized. Although this study demonstrated the ability of $A$. avenae subsp. avenae to infect and cause disease on creeping bentgrass, the phenomenon of early-stage etiolation is still relatively uncharacterized. We hypothesize that the natural infection of the bacterium at low to moderate levels during cooler temperatures causes a physiological or hormonal response in the plant by which elongation of the newest shoot and leaf occurs. Observations of this atypical growth habit can also be observed in annual bluegrass (P. апnua var. annua) infected with the bacterial pathogen Xanthomonas translucens pv. poae (6).

The bacterium $A$. avenae subsp. avenae is a common seedborne pathogen $(3,7,13,30,31)$ in graminaceous species, and has long been considered a weak pathogen of most hosts, having only minor economic impact in corn, oat, rice, and millet $(4,5)$. More recently, however, A. avenae spp. have caused severe losses in rice throughout the world (17), and have emerged as the cause of numerous diseases of importance on other hosts as well $(11,19,26,28)$. The emergence of $A$. avenae subsp. avenae as a pathogen on turfgrass is consistent with observations in other cropping and planting systems. Extreme environmental conditions, particularly high temperatures, sustained humidity, and periods of heavy rainfall in many regions of the United States, have made an already intensively managed species such as creeping bentgrass increasingly difficult to manage in summer months. Infection of creeping bentgrass by A. avenae subsp. avenae and the rapid population of tissues during high heat and humidity results in necrosis and plant death. Latent infection of A. avenae subsp. avenae has been observed in rice $(30,31)$, in which asymptomatic plants harbor the bacterium and are able to transmit infection from plant to seed, and symptom development is favored by high temperature and humidity. Until a robust diagnostic assay for the turfgrass pathogen is developed, the existence of latent infection among turfgrass stands is still uncertain. It is also unclear, based on $16 \mathrm{~S}$ rDNA sequencing, how closely related the turfgrass pathogen is to other plant-pathogenic A. avenae subsp. avenae. Genetic and genomic analyses related to host specificity and phylogenetic divergence are underway.

"Bacterial brown stripe" is a name given to the disease caused by A. avenae subsp. avenae on creeping bentgrass in Japan (10). Although this original name was likely adopted to match nomenclature to diseases caused by A. avenae subsp. avenae on other hosts (i.e., corn, rice, sugarcane, and so on), the symptoms on creeping bentgrass in the United States tend to be those of chlorosis, etiolation, necrosis, and decline rather than brown striping. Therefore, we refrain from using this terminology and recommend the disease be referred to as bacterial etiolation or bacterial decline. Bacterial infection of creeping bentgrass has been considered a stress-related condition on golf course putting greens, and is thought to be exacerbated by low heights of cut and aggressive cultural practices such as sand top-dressing and grooming. The emerging problem associated with $A$. avenae subsp. avenae infection on turfgrass is likely stress induced. Daily mowing, frequent aggressive cultural practices, and heavy traffic are all effective means by which inoculum can spread to neighboring plants throughout a turfgrass stand. Symptoms are not often observed on turfgrass that is kept at higher heights of cut or subjected to less rigorous maintenance regimes. Control options for bacterial diseases in turfgrass are extremely limited. More work remains in characterizing appropriate cultural and potential chemical control options for this emerging disease on golf course putting greens.

\section{Acknowledgments}

We thank The United States Golf Association for providing the funding for this research; and MSU AgBioResearch, as well as J. Kent and other golf course superintendents, for their cooperation and shipment of turfgrass samples.

\section{Literature Cited}

1. Ark, P. A., and Thomas, H. E. 1946. Bacterial leaf spot and bud rot of orchids caused by Phytomonas cattleyae. Phytopathology 36:695-698.

2. Browning, M., Mitkowski, N. A., and Jackson, N. 2002. Xanthomonas spp. affecting golf course putting greens in the Northeast. (Abstr.). Phytopathology 92:S10.

3. Claflin, L. E., Ramundo, B. A., Leach, J. E., and Erinle, I. D. 1989. Pseudomonas avenae, causal agent of bacterial leaf stripe of pearl millet. Plant Dis. 73:1010-1014.

4. Cortesi, P., Bartoli, F., Song, W. Y., and Schaad, N. W. 2005, First report of Acidovorax avenae ssp. avenae on rice panicle in Italy. J. Plant Pathol. 87:75-76.

5. Cottyn, B., Cerz, M. T., and Mew, T. W. 1994. Bacterial pathogens. Pages 91-96 in: A Manual of Rice Seed Health Testing. T. W. Mew and J. K. Misra, eds. International Rice Research Institute, Manila, The Philippines.

6. Dernoeden, P. H., Jackson, N., Mitkowski, N., and Kaminski, J. E. 2003 Bacterial wilt: An enigmatic annual bluegrass disease of putting greens. Golf Course Manage. January 2002:177-180.

7. Fahy, P., Gillings, M., Bradley, J., Diatloff, A., and Singh, S. 1989. Use of fatty acid profiles and restriction fragment length polymorphism to trace a quarantine outbreak of Pseudomonas avenae on French and Italian millet. Pages 491-496 in: Z. Klement. Proc. 7th Int. Conf. on Plant Pathogenic Bacteria, Budapest.

8. Fett, W., Osman, S., and Dunn, M. 1987. Auxin production by plant-pathogenic Pseudomonads and Xanthomonads. Appl. Environ. Microbiol. 18391845 .

9. Fidanza, M., Gregos, J., and Brickley, D. 2008. Are etiolated tillers a visual nuisance or something else? Turfgrass Trends Golfdom October:60-61, 64.

10. Furuya, N., Ito, T., and Tsuchiya, K. 2009. Occurrence of bacterial brown stripe of creeping bentgrass on golf course green in Kyushu. J. Fac. Agric. Kyushu Univ. 54:13-17.

11. Gardan, L., Dauga, C., Prior, P., Gillis, M., and Saddler, G. S. 2000. Acidovorax anthurii sp. nov., a new phytopathogenic bacterium which causes bacterial leaf spot of anthurium. Int. J. Syst. Evol. Microbiol. 53:253-246.

12. Giordano, P. R., Vargas, J. M., Jr., Detweiler, A. R., Dykema, N. M., and Yan, L. 2010. First Report of a bacterial disease on creeping bentgrass ( $A g$ rostis stolonifera) caused by Acidovorax spp. in the United States. Plant Dis. 94:922.

13. Gitaitis, R. D., Stall, R. E., and Strandberg, J. O. 1978. Dissemination and survival of Pseudomonas alboprecipitans ascertained by disease distribution. Phytopathology 68:227-231.

14. Hu, F. P., Young, J. M., and Triggs, C. M. 1991. Numerical analysis and determinative tests for nonfluorescent plant-pathogenic Pseudomonas spp. and genomic analysis and reclassification of species related to Pseudomonas avenae Manns 1909. Int. J. of Syst. Bacteriol. 41:516-525.

15. Hu, F. P., Young, J. M., Triggs, C. M., and Wilkie, J. P. 1997. Pathogenic relationships of the subspecies of Acidovorax avenae. Australas. Plant Pathol. 26:227-238.

16. Kadota, I., and Ohuchi, A. 1983. Symptoms of bacterial brown stripe of rice seedlings in nursery boxes. Ann. Phytopathol. Soc. Jpn. 49:561-564.

17. Kihupi, A. L., Mabagala, R. B., and Mortensen, C. N. 1999. Occurrence of Acidovorax avenae subsp. avenae in rice seed in Tanzania. Afr. Plant Prot. 5:55-58.

18. Knowles, J. 2011. Ghost grass: Jonathan Knowles enters the spooky world 
of ghost grass. Greenkeeper Int. July:24-25.

19. Latin, R., and Hopkins, D. L. 1995. Bacterial fruit blotch of watermelon. Plant Dis. 79:761-765.

20. Marchesi, J. R., Sato, T., Weightman, A. J., Martin, T. A., Fry, J. C., Hiom, S. J., Dymock, D., and Wade, W. G. 1998. Design and evaluation of useful bacterium-specific PCR primers that amplify genes coding for bacterial $16 \mathrm{~S}$ rRNA. Appl. Environ. Microbiol. 64:795-799.

21. Mitkoski, N. A., Browning, M., Basu, C., Jordan, K., and Jackoson, N. 2005. Pathogenicity of Xanthomonas translucens from annual bluegrass on golf course putting greens. Plant Dis. 89:469-473.

22. Ramundo, B. A., and Claflin, L. E. 1990. Demonstration of synonymy between the plant pathogens Pseudomonas avenae and Pseudomonas rubrilineans. J. Gen. Microbiol. 136:2029-2033.

23. Roberts D. L., and Vargas, J. M., Jr. 1984. Bacterial wilt: a potentially devastating threat. Golf Course Manage. 33:37-41.

24. Roberts, D. L., Vargas, J. M., and Detweiler, R. 1985. Occurrence of bacterial wilt on Poa annua and other turfgrasses. (Abstr.) Phytopathology 75:1289.

25. Sands, D. C., Schroth, M. N., and Hildebrand, D. C. 1980. Pseudomonas, Pages 36-44 in: Laboratory Guide for Identification of Plant Pathogenic Bacteria. N. W. Schaad, ed. American Phytopathological Society, St. Paul $\mathrm{MN}$.

26. Schaad, N. W. 2008. Emerging plant pathogenic bacteria and global warm- ing. Pages 369-379 in: Pseudomonas syringae Pathovars and Related Pathogens-Identification, Epidemiology and Genomics. M. Fatmi, A. Collmer, N. S. Iacobellis, J. W. Mansfield, J. Murillo, N. W. Schaad, and M. Ullrich, eds. Springer, New York.

27. Schaad, N. W., Kado, C. I., and Sumner, D. R. 1975. Synonymy of Pseudomonas avenae Manns 1905 and Pseudomonas alboprecipitans Rosen 1922. Int. J. Syst. Bacteriol. 25:133-137.

28. Schaad, N. W., Postnikova, E., and Randhawa, P. 2003. Emergence of Acidovorax avenae subsp. citrulli as a crop threatening disease of watermelon and melon. Pages 573-581 in: Pseudomonas syringae and Related Pathogens. N. S. Iacobellis et al., eds. Kluwer, Dordrecht, The Netherlands.

29. Schaad, N. W., Sowell, G., Goth, R. W., Colwell, R. R., and Webb, R. E. 1978. Pseudomonas pseudoalcaligenes subsp. citrulli subsp. nov. Int. J. Syst. Bacteriol. 28:117-125.

30. Shakya, D. D., Chung, H. S., and Vinther, F. 1986. Transmission of Pseudomonas avenae, the cause of bacterial stripe of rice. J. Phytopathol. 116:9296.

31. Shakya, D. D., Vinther, F., and Mathur, S. B. 1985. World-wide distribution of a bacterial stripe pathogen of rice identified as Pseudomonas avenae. J. Phytopathol. 114:256-259.

32. Thorn, G., and Tsuneda, A. 1996. Molecular genetic characterization of bacterial isolates causing brown blotch on cultivated mushrooms in Japan Mycoscience 37:409-416. 